DOI: $10.1515 / \mathrm{abcsj}-2015-0012$

\title{
Experimental Language Deconstructing Patriarchal Discourse in Ntozake Shange's for colored girls who have considered suicide/ when the rainbow is enuf
}

\author{
SILVIA MARA TELLINI
}

Sao Paulo State University

\begin{abstract}
By sharing the experiences of women and the black community of her time, represented as a journey towards womanhood on stage, AfroAmerican playwright Ntozake Shange deconstructs the patriarchal structure of language, by pushing the boundaries of genres as she assembles prose, poetry and stage performance in a "choreopoem" capable of empowering and liberating the trajectories of the represented black women. The present study explores the semiotic and linguistic deconstructions of the patriarchal ideology in for colored girls who have considered suicide/ when the rainbow is enuf, aiming at a discussion of the author's experimentalism with language outside instituted discursive paradigms regarding women. Considering that the concept of the liberation of the individual is strongly historicized in the play, the characters of the seven ladies are focalized as being tightly related to the feminist movement in North America in the seventies. Furthermore, the implications of ideological impositions and limited roles for women in society are analyzed.
\end{abstract}

Keywords: Ntozake Shange, Afro-American literature, theater, poetry, cultural studies, feminism, women's studies, semiotics

"my spirit is too ancient to understand the separation of soul \& gender"

(Ntozake Shange) 


\section{Introduction}

Born Paulette Williams on October 18, 1948, Shange, at the age of twenty-three, adopted the Zulu names Ntozake, meaning "she who comes with her own things," and Shange, meaning "who walks like a lion," since she felt her Anglo-Saxon name was associated with slavery. Like many other Afro-Americans in the nineteen seventies, the author was active in the wave of the Civil Rights Movement, and she renamed herself in an African tribe language in order to dissociate her identity from the hegemonic white Anglo-Saxon culture, which had historically imposed itself through slavery. On a more private level, Shange believed her new identity worked as a process of reinforcement of her inner strength, after a period of depression, a time when she had attempted suicide a number of times.

Shange grew up in a middle-class family and read in English, French, and Spanish. She met jazz singers and players such as Josephine Baker, Chuck Berry, Miles Davis, Dizzie Gillespie, and Charlie Parker, who were friends of her parents. She explained, in an interview to Jacqueline Trescott from the Washington Post, that "in those days nobody was expecting me to do anything because I was colored and I was also female, which was not very easy to deal with" (Rushing 542).

After graduating, she moved to Harlem and came face to face with the impoverished and violent situation some black women were going through. The anger she experienced is expressed in for colored girls who have considered suicide/ when the rainbow is enuf in the poem "Beau Willie" adapted in the play as "a nite with beau willie brown," which she remembers writing while listening to the screams of a woman being beaten up by her husband, who laughed as he hit her.

She mentioned during an interview that the idea for the title of the play came to her one night while driving home, after teaching an evening class, at a time when she was feeling especially depressed. She saw a huge rainbow over the city of Oakland, California, and realized that women had a right to survive, because they "have as much right and as much purpose for being here as air and mountains do." In that same interview, Shange 
explained that she realized that the rainbow is "the possibility to start all over again with the power and beauty of ourselves" (Rushing 542).

Her insight inspired the title for colored girls, composed of twenty poems she wrote over a period of years, which she was eventually able to read and perform at a women's bar in San Francisco, during the summer of 1974. While she taught humanities, women's studies, and AfroAmerican studies, she was dancing and reciting poetry with her own company which was also called for colored girls.

Soon enough, she moved to New York where her play was first produced Off-Broadway, by Joseph Papp, in 1975. Papp had become well-known due to his struggle for making Shakespeare's work become accessible to the public as well as for establishing The Public Theatre, with many small theaters focusing on new, experimental productions. Shange's play moved from The Public to Broadway, allowing her to be the second Afro-American woman to reach the mainstream stage in the United States and to become the award winner of many prizes, including the Obie Award.

The play unravels issues concerning the lives of black women in the United States, tackling not only on racial tensions outside the black community, but also revealing forces and tensions of domination, submission and segregation within the community itself, such as those involving violence against black women perpetrated by black men. The stage play was born from poems and was first published in book form in 1977. Her courage to expose some of the issues her society pretended were inexistent, cost her some animosity amongst the most patriarchal Afro-Americans, who left the theater amongst boos before the end of some of the performances.

When the play was adapted to a motion picture, bearing the same title in 2010, Shange stated that she saw her play then, as "gray slate clouds, ominous and dense, (which) give away to a pastel prism of color, dancing cross the sky," while adding that she "looks forward to discovering more colors to add to the rainbow that is this colored girl's wonderful journey" (16). Her statement may hint on why this play has been continuously performed throughout the United States and abroad, being of interest to many different field studies in various academic 
institutions up to today. She is aware of her poems as stage performance addressing not only issues of her own time and society, but also conveying a strong belief in the transformation of individuals and communities.

\section{The Choreopoem or Language out of Patriarchal Ideology}

Women's struggle for the right to a dignifying place in the world had had other representatives amongst authors from other continents before the feminist wave in North America in the seventies. Shange seeks the liberation of black women from a double hegemonic subjugation in North America, through her search for a free expression of the language.

The usage of language to enforce ideological regulations had already been a concern for Virginia Woolf (1882-1941) since the modern Georgian period in England. She had advocated for the right of words to express significations beyond their captured meanings in dictionaries, that is, their right to be free from the prejudice expressed in the grammatical rules imposed by the white English men of her society.

In the only recording of her voice for the BBC radio broadcast, which contained a part of her text The Death of the Moth and Other Essays, published in 1942, Woof states that "words do not live in dictionaries, but in the mind" (1937); she poetically describes the way language thinks us and the world not as separate entities, but rather as codependent beings that can only signify if conceptualized as worlds in transit. In other words, in literature the subjective "I" can only be identified in an exchange of interrelations with the "other" and the world, and thus, become manifest in alterity. In her interview, Woolf (1937) illustrates that "English words marry Negro words," "Indian words can marry uneducated words" and that "old words can marry new words." Although her choice of words is considered anachronic and unacceptable today, provided that she writes from a colonial historical context, what matters here is that Woolf states that language is an area within which the plurality of our minds and experiences can be discovered in a dialogical process which does not disregard, or seek to eliminate, differences, but rather can only be established in difference. 
In other words, Woolf and Shange are both aware that the representations of the "I" are fragmented, fractured and incomplete, as they are subject to the fluidity of transformations deriving from encounters with that "other."

Furthermore, in A Room of One's Own, Woolf explains that "one can only give one's audience the chance of drawing their own conclusions as they observe the limitations, the prejudices, the idiosyncrasies of the speaker" (5). What the writer asserts is that the search for possibilities of representation of us to ourselves and the "other" can only be constructed in a flawed and incomplete interdependency, which should have its limitations unveiled.

In for colored girls, Shange exposes the idiosyncrasies and prejudices of her society, through the deployment of verbal and nonverbal elements. Her voice in this play seems to be in alignment not only with Woolf's conceptions of experience and language beyond the imposed regulated grammar, but also with Simone de Beauvoir's philosophical work, which produced a deep impression on Shange's mind. In a number of interviews, the playwright has claimed to be familiar with the works of both Woolf and de Beauvoir, to mention only two of the feminist references with which she had come into contact.

The struggle against the idea of the female as the "other," which can only exist to the detriment of the concept of the male (the castrated male), created an intense discussion initiated by the French author in the fifties. Hence, it is not surprising that just like some black men felt they should speak against Shange's play in the seventies, it is common knowledge that some of de Beauvoir's partners from the existentialist movement also had trouble digesting her positions a couple of decades before. Nonetheless, Shange continues to demystify the concept of woman as a second-class gender.

The discussion of feminist issues throughout the play is apparent and, yet, deep. The opening shows seven women dressed in the colors of the rainbow, plus a lady in brown. As the lady in brown comes to life, out of a freezing pose, she performs the poem dark phrases (3-7), which speaks of the trials of a young black girl growing into womanhood in America. It anticipates the tone which will permeate the play, insofar as it 
approaches the situation of black girls who have been silenced and are struggling to exist. Nevertheless, the lady in brown claims that she still possesses a voice, even if it is heard only in "haf-notes scattered" (5). As Woolf had prescribed in A Room, Shange gives the audience that chance to listen to the limitations and idiosyncrasies of society, to listen to a black girl's song which cannot be heard as a whole, reaching society only in a fragmentary, spooky and hysterical tone. This lady sings about how difficult it is even for herself to hear her own voice:

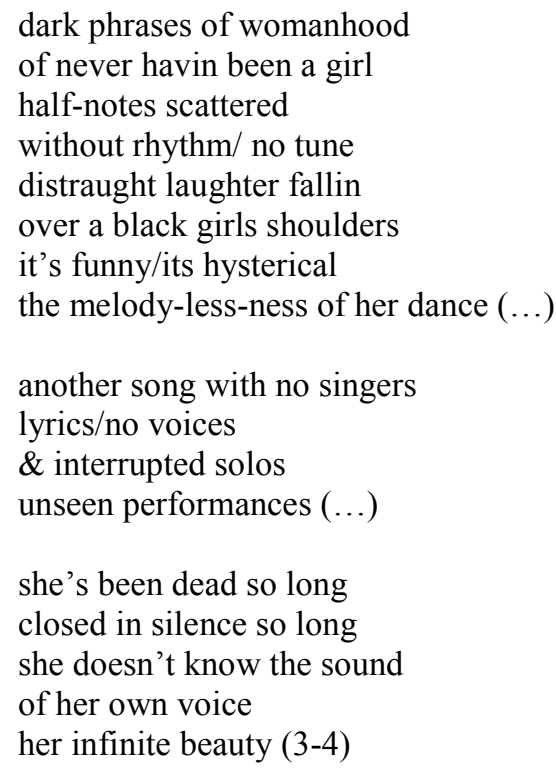

While the lady in brown is singing her poem, the other ladies on stage remain still, in dead silence. The lady in brown says she "can't hear anything/but maddening screams \& the soft strains of death" (4), as she has been locked up in silence. The opening poem addresses the struggle of the ladies to be heard, to come out of silence and be born, which symbolizes how difficult it is to be themselves in their society. Shange addresses the limitations and even deaths of the symbolic and physical lives of women, whose voices cannot be heard integrally, since they must comply with the hegemonic patriarchal impositions. On stage, the multiple dimensions of the lady in brown's struggle are echoed in all the other ladies' lines sung to each other, and together as one voice. 
Before the lady in yellow starts the prose-poem graduation nite, the other six women repeat after the lady in brown says "let her be born" no matter where she is from, be it from "outside Chicago," "outside Detroit" or "outside Houston" (5).

The drama in the scene is magnified by dim blue lights, emerging out of darkness, to show the frozen bodies of the other ladies, who perform a rhythmic repetition of the semantics of "the outside" (5). Moreover, the opening of the play also emphasizes the fact that when the dimensions of these ladies' voices are not heard, or worse, when their discourses suffer from being muffled, it means that a great deal of their existence is denied. Shange points out that their inner comprehension of their beauty is interrelated with the comprehension of their society in understanding their being entitled to difference.

Woolf (4) had approached the issues between women and society through fiction, as she affirmed that significations emerge not only out of the concept of who a woman was, but also out of what a woman wrote. Beyond that, she acknowledged a third dimension, which encompasses what is written about women, in other words, the ideologies constructed through discourse which have the power to deprive women of their rights.

Suitably the opening scene is pervaded with the idea of emptiness, materialized in the dark stage, dimming light and lack of movement, which contrasts which the progressively growing variety of dancing and playful movements, meanwhile the verbally contained verses unfold in amplified, long verses, which will escalate into the poem-prose graduation nite.

At this point, although the poem bears no resemblance thematically, it analogically resembles Walt Whitman's poetry in terms of structure. Like Whitman's stylistic tone, Shange also has the ability to create free verses, containing a melodic soulful rhythm, produced out of counterbeats, which reminds us of a melodic jazz improvisation.

In this prose-poem, particularly, the melodic lengthy verses provoke an acceleration of the pace, which reproduces the excitement of the lady in yellow for being flattered by a male's physical attraction to her, as we can follow below: 


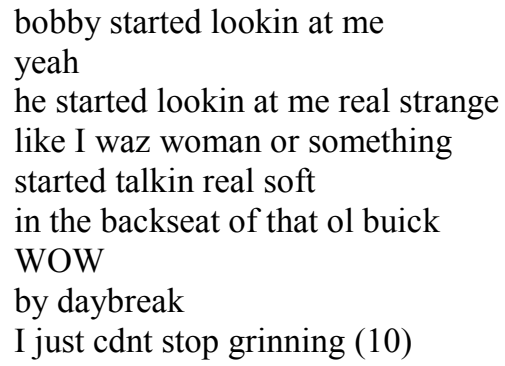

Lamia K. Hammad understands that "some radical feminists might attack Shange's openness in having this woman's femaleness defined by a male" (262). Nevertheless, this encounter demonstrates that Shange does not believe every encounter with a male to be a threatening one, even in matters of sexuality. During this passage, the lady in yellow describes a party with dance, punch, and girls "making out" with boys, which will lead to a climax, when she loses her virginity. She is proud to announce to her friends that she has "given it up in a buick" (10), as she narrates her graduation night:

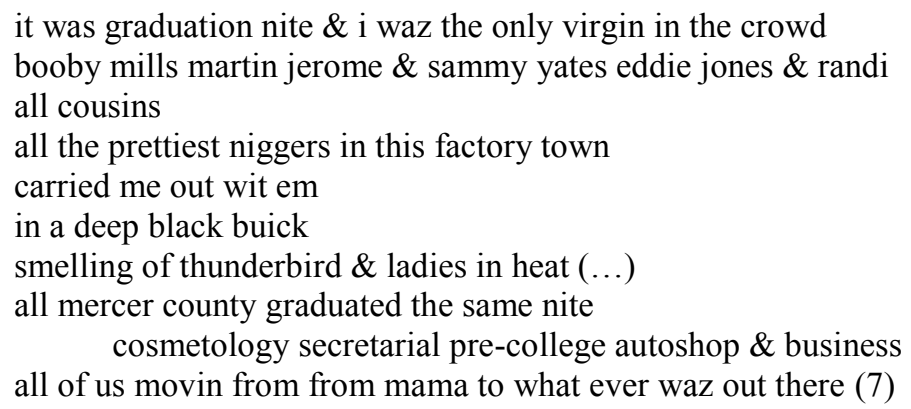

The semiotic elements intertwined with her voice are expressed in the dance performed by the other ladies to Dancing in the Streets (1964), sung by Martha and the Vandellas, progressing to the song Stay in My Corner (1965) by the Dells, as the scene closes up.

These songs' lyrics complement each other in their contrasting tones. The lyrics of Dancing in the Streets cheerfully call out people around the world to know whether they "are ready for a new brand beat" (1964), since it is summer and time to change. The music and dance in this scene sustain the experimentalism in different dimensions 
concomitantly. The visual, musical and prose-poetry languages converge to the expression of a moment of transformation and liberation towards growing up into a woman. From a thematic perspective, both songs are emblematic of the narration in the scene. Stay in my Corner (1965) is a mellow romantic pledge of a man for a woman to stay with him because he has fallen in love with her. As the lady in yellow moves freely to the song, she narrates her romantic encounters: "martin slipped his leg round my thigh ... bobby whispered I shd go wit him" (9-10).

Linguistically, not only the length of the verses composes the pace of the scene, but also the absence of punctuation, as well as the absence of capitalized letters, which intensifies the continuous and rhythmic flow of information. The author uses few " $\&$ " (and), despite privileging the concatenation and coordination of information.

The condensation of information is intensified by the jamming of the verses one after the other, which is graphically represented in the spatiality of the page, as verses appear in an untidy and loose manner, without fixed indentation. This visual resource translated into the speech of the performer, will convey the tone of the chaotic and cheerful rhythm of the moment.

From the commented passages, one is able to perceive that Shange seeks to disrupt English grammar, inasmuch as she emphasizes the language used in her community, which is vital to allow the melody of the ladies' voices to be heard also as a unified voice, gaining strength to overcome imposed discourses.

Furthermore, regarding the contextualization conveyed in the verses, the lady in yellow speaks of a neighborhood in the projects, at a time of important rituals for young women, as they are about to leave their "mamas" houses" (7) to become officially adults.

Conversely to this cheerful celebratory passage, Hammad refers to the choreopoem about abortion, abortion cycle number 1 , as one of the most relevant. She claims it is not an attack on men, but rather a denouncement of a patriarchal society that rejects women who celebrate their sexuality, specifically a society that "makes a woman's biology her destiny of shame" (262), as we follow the lady in blue deliver: 




She fears the situation and feels powerless as she is depicted lying down with her legs spread open, waiting for the operation to be over. As she goes on describing her experience, the verses become shorter and shorter, as if she was lacking strength and becoming exhausted. The fact that she is alone and nobody can know about her abortion, or when it is happening, denounces society's approach to women in fragile situations as it becomes easier to cast them out. Nevertheless, abortion continues to be a controversial issue today, a theme which can be analyzed in the play from a broader critical perspective, also as a denouncement against the oppression deriving from any verticalized power relationship.

In this poem, once again Shange contextualizes a problem of the Afro-American community to which she belonged. In the documentary What Happened, Miss Simone?, directed by Liz Garbus (2015), Nina Simone questions: "How can you be an artist and not reflect the times?" That is Shange's position, who chose to reflect her time and to retell some of her personal experiences on stage.

In cultural studies, discourse is understood as always related to power. Its logics wield power to some, while excluding others. What some 
feminists have focused on since the turn of the nineteen century regards the oppression of women by a male-controlled language, which entraps women's truth in a hegemonic patriarchal world. The dual dominantsubordinate relation impoverishes the world through misrepresentations and stereotypes.

Gilbert and Gubar, in The Madwoman in the Attic, discuss the search for a literary paternity where the male authority uses his "pen-is" to write his hegemonic discourse (3-44). Therefore, the male author "fathers" his texts, so the feminine is ruled (out) and systematized through a hierarchy in a paternal structure. Hammad explains how that relation generates a male text which is "sword like because it deals with the female discourse harshly in a way that confines them to what is legitimate from a paternal point of view, in this hegemonic discourse where the paternal cannot tolerate the feminine" (259) .

In Shange's play, the harsh binary-like relationship is reiterated in scenes such as that of Crystal and Beau-Willie Brown. The scene is one of the most commented as it portrays a war veteran who decides to throw his son and daughter out of the window since Crystal refuses to marry him, as we can follow below:

he came home crazy as hell/ he tried to get veterans benefits to go to school \& they kept right on puttin him in remedial classes/ he cdnt read wortha damn/ so beau cused the teachers of holdin him back \& got himself a gypsy cab to drive/ but his cab kept breakin down/ \& the cops was always messin wit him/ plus not gettin much bread (...)

i aint gonna marry ya/ i aint ever gonna marry ya/ for nothin/ you gonna be in the jail/ you gonna be under the jail for this/ now gimme my kids/ ya give me back my kids/

he kicked the screen outta the window/ \& held the kids offa the sill/ you gonna marry me/ yeh, i'll marry ya/ anything/ but bring the children back in the house/ he looked from where the kids were hangin from the fifth story/at alla the people screamin at him/ \& he started sweatin again/ say to alla the neighbors/ you gonna marry me/ i stood by beau in the window/ with naomi reachin for me/ \& kwame screamin mommy mommy from the fifth story/ but i cd only whisper/ \& he dropped emp (55-56, 59-60)

Sandra Flowers asserts that, in this passage, "Shange demonstrates a compassionate vision of black men because though the work is not without anger, it has certain integrity" (51). Therefore, the issue of women 
acting out as subordinate or submissive partners also requires men to liberate themselves from unequal relationship patterns. Beau Willie is a man who is unable to make a living on his own, after he is denied his veteran benefit and is constantly chased by the police when he becomes a taxi driver. He suffers the impact of an unequal social system which oppresses him, whereas he is certain of being in control of his own life. In that regard, Hammad claims that Shange acknowledges that black males are indeed victimized by a system of social and racial inequality (261-2). Nevertheless, she demonstrates in the infanticide scene that she does not find in that situation an excuse for the brutality of abusive behavior against women. Moreover, women like Crystal are also conniving with the patriarchal system, insofar as she can only function in an abusivedestructive relationship, stimulating the maintenance of that logic as an alternative to women.

The performed prose-poem places the audience inside the room of the couple, whose arguments will climax to the tragic dispute, but is also descriptive of the outside space, the streets from where people observe the unfolding of the tragic event. Inside the room, the verses switch from Crystal's screaming to Beau Willie's cursing, in a violence inscribed in the broken verses and unfinished lines until Beau's uncontrolled actions reach a sudden silence, confirming his killing the children as Crystal utters her shock: "but i cd only whisper/ \& he dropped emp" (60).

Considering the social contextualization, Sandra Richards asserts that "references to these social factors are indeed present" (77), which bring into debate the destructive impact of the dominant culture's expectations on relationships. Although Beau Willie kills his own children, for Richards the scene emphasizes "Shange's anger in response to the circumstances and impulses which result in men brutalizing women" (Flowers 53).

The scene is followed by a series of words recited by all the ladies which become a unison until the consonance unfolds in the last scene as the lady in blue claims: "all the gods comin into me / laying me open to myself" (61), followed by the ladies repeating all together and to themselves: "i have found go in myself / \& I loved her fiercely" (63). Shange finds resolution in something uncommon to Afro-American 
religions, which seems to resonate more with the feminists that preceeded Shange and had influenced her as contextualized here (Rushing 542). In African religions, divine entities are often represented by both female and male deities. The love of a god which is only one and a "she" seems to claim for women the right to an empowered voice.

Furthermore, Barbara F. Waxman asserts that in Western cultures, dancing and singing together are seen as empowerment activities, such as in religious rituals (91). Likewise, in Western literature, the celebratory ending has been a tradition since Shakespeare's comedies. Dancing can also resemble rituals in modern American popular culture once it has been symbolized as the opportunity for the individual to achieve selfexpression.

Hammad highlights the fact that the semiotics functioning in Shange's play are "disruptive of all structures created by the self, because the self is recreated through the changing reflexes of the semiotic body movements" (264), that is, by refusing the normalization, the self gains a colorful, non authoritative identity. The choreography is thus selfaffirming of the body that will not be denied. Out of the rhythm of the poetry, singing and dancing that emerge from within and without the seven ladies, in seven colors, anonymously and in togetherness, they find that "god in themselves" (Shange 63), not as a separate and fixed empowered identity, but rather as an inner identity thriving in possibilities.

Ultimately, according to Andrea B. Rushing, beyond the representational troubling realities of violence perpetrated by black men against black woman, or the "pro-lesbian thrust" some detected in the story, the play is groundbreaking in terms of presenting black women in different roles they had never been seen staged previously (540). Black women had been portrayed alternately as domestics like "Beulah," stalwart matriarchs like "Mama Younger," in The Raisin in the Sun or the "hot-blooded exotics like Carmen Jones."

The French feminist Helen Cixous agrees that in order to transgress the phallocentric discourse, a woman needs to "invent for herself a language to get inside" (309), since she already found herself using a male-dominated discourse. Shange's poems were written over a few 
years, and since the beginning of the play, the ladies in different colors announce they have histories to be told which do not conform with the hegemonic discourse, but rather come from different places and backgrounds.

Ambiguously, it was due to the playwright's pertinent criticism and denouncement of the hegemonic power that the play appealed to a more commercial venue on Broadway, which in turn, influenced her to reject the play as her main work years later, while she was creating installations of artwork she considered non-commercial. When asked about the lack of other commercial successes, she commented in an interview for the Black Women Writers:

The commercial people tell me that one of the reasons the rest of my work hasn't been as commercially successful as for colored girls is that it has no point that they could sell. That's because there's going to be no more point. I am not writing about a point. for colored girls doesn't have a point either, but they made a point out of it. Those girls were people whom I cared about, people whom I offered to you for you to see and to know. Black and Latin writers have to start demanding that the fact that we're alive is point enough. (qtd. in Hammad 259).

Regardless of the debate on whether the commercial success of the play was beneficial, Rushing discusses the extent to which the play stands out on account of Shange's in-depth studies (539-550), approaching "black women's body language and styles of speech carefully" (540). The play portrays "her vision of black women as the plot starts in a nostalgic reference and then progresses to include references to the present lives of their adult selves at a time when they had given up hope of ever seeing themselves transformed into stage art" (540). Such art form is a political statement insofar as it shows the heterogeneity of women's physical and emotional experiences, as they find hope in their own inner voices transformed along the performance. Shange's offering invites us to experience the world as in one of those days, after the rain, when the freshness in the air brings momentarily some new empowering sounds, telling us of different possible realities. In the play, it is the lady in brown, not a color in the rainbow, who is the announcer of a rejuvenated possible existence. 


\section{Conclusion}

One cannot but be in awe before Shange's for colored girls' brilliant aesthetic features, easily felt in her innovative and powerful experiment in rewriting a new English grammar. She was able to courageously find, within herself, enough freedom in order to experiment with the rewriting of a canonic English language, adding a far more colored and colorful language to it, honestly and openly related to her own world experiences. The choreopoems combine music, song, dance and poetry. Along with that idea, one can see that language is not the thing itself, but rather a representation of the thing, which therefore encompasses non-verbal ways of communication.

The experimentalism in mixing different semiotic systems, as well as the manner in which Shange treats the language by bringing written words closer to black women's real accents and cultural features, compose an artistic structure that denounces the logics of a patriarchal society.

Therefore, the present essay argues that the power of Shange's voice can neither be undermined, nor be reduced to a supposedly outdated history, restricted to a ghetto of African American women in the era of the Civil Rights Movement. Dimensions of the ideologies restricting the life of women in the Afro-American community are understood as representative of current discussions encompassing minority groups today, especially those concerning women's issues. In order to support that, the linguistic and semiotic features of the play, which privilege a liberating language form, are discussed in relation to the process of impoverishment of symbolizations when oppressive verticalized relations are dictated. Simultaneously, the new language is also analyzed as a driving symbolic force for both women and their community, who can now envision the possibility of enriched existences in their interrelations with the different colors in the world. In other words, as the lady in brown concludes at the end of the choreopoem, life itself is enough to be worth living in the rainbow of womanhood (64). 


\section{Works Cited}

Boston College. BC Theatre. 2014. Web. 01 June 2015.

Beauvoir, Simone de. Balanço Final. Trans. Rita Braga. Rio de Janeiro: Nova Fronteira, 1982. Print.

---. The Second Sex. Trans. Constance Borde and Sheila Malovany-Chevallier. New York: Random House, 2010. Print.

Cixous, Helene. The Laugh of the Medusa. Critical Theory Since 1965. Eds. Hazard Adams \& Leroy Searle. Tallahassee: University Press of Florida, 1986. 309-321. Print.

"Craftsmanship." Interview with Virginia Woolf. BBC Radio Broadcast. 20 April 1937. Web. 15 June 2015.

El-Shayal, Dalia. Nonverbal Theatrical Elements in Ntozake Shange's "for colored girls..." and Intissar Abdel-Fatah's "Makhadet El-Kohl” (The Kohl Pillow). Comparative Drama 37. 3-4 (2003-04): 361-378. Web. 06 June 2015.

Flowers, Sandra Hollin. "Colored Girls: Textbook for the Eighties." Black American Literature. 15.2 (1981): 51-54. Web. 22 March 2010.

Gilbert, Susan, and Sandra Gubar. The Madwoman in the Attic: The Woman Writer and the Nineteenth-Century Literary Imagination, 2ed., New Haven: Yale University Press, 2001. 3-44. Print.

Hammad, Lamia Khalil. Black Feminist Discourse of Power in For Colored Girls Who Have Considered Suicide. Jordan: Yarmouk University, 2011. Web. 01 June 2015. PDF File.

Martha and the Vandellas. "Dancing in the Streets." Online video clip. You Tube. You Tube. 30 May 2008. Web. 20 October 2015.

Richards, Sandra L. "Conflicting Impulses in the Plays of Ntozake Shange." Black American Literature Forum 17. 2 (1983): 73-8. Web. 10 March 2015.

Rushing, Andrea. B. "For Colored Girls, Suicide or Struggle." The Massachusetts Review 22. 3 (1981): 539-550. Web. 01 June 2015.

Shange, Ntozake. For Colored Girls Who Considered Have Considered Suicide/ When the Rainbow is Enuf. New York: Simon \& Schuster Inc., 1997. Print.

What Hapenned, Miss Simone?. Dir. Liz Garbus. Perf. Nina Simone. Netflix, 2015. Film.

The Dells. "Stay in My Corner." Online video clip. You Tube. You Tube. 29 May 2013. Web. 20 October 2015.

Waxman, Barbara Frey. "Dancing out of Form, Dancing into Self: Genre and Metaphor in Marshall, Shange, and Walker." Mellus 19. 3 (1994): 91-106. Web. 18 October 2015.

Whitman, Walt. Songs of Myself. London: Penguin Books, 1986. Print.

Woolf, Virginia. A Room of One's Own. London: Penguin Books, 1965. Print. 